\title{
Where Have The Mediating Variables In Leadership-Performance Research Gone?
}

Fenwick Feng Jing, Macquarie University, Australia

Gayle C. Avery, Macquarie University, Australia

\begin{abstract}
The literature suggests that variables such as using a vision, organizational climate, and trust between leader and followers may mediate the relationship between leadership and organizational performance. Yet, existing research tends to ignore these potentially important variables. This paper addresses this gap, discusses the overlooked variables, and suggests directions for future research via 14 research propositions.
\end{abstract}

Keywords: mediating variables, leadership-performance relationship, vision, climate, trust

\section{INTRODUCTION}

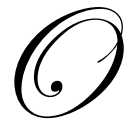

ver recent decades, this question of whether leadership affects organizational performance has received considerable attention from both researchers and practitioners. Despite increased research into the leadership-performance relationship, methodological problems characterize existing studies, particularly a failure to include mediating variables.

This paper aims to highlight gaps in the existing literature and guide future research by identifying mediating variables that should be considered when researching the relationship between leadership and organizational performance. The paper begins with a discussion of the importance of mediating variables and the potential mediating roles of three often-neglected variables affecting the leadership-performance relationship. A set of research propositions is generated. The paper then summarizes the gaps shown in the current literature and concludes by showing that multiple mediating variables need to be considered in future leadership-performance research.

\section{IMPORTANCE OF MEDIATING VARIABLES}

Over the past four decades, the impact of leadership styles on organizational performance has been a topic of interest among leadership academics and practitioners (Cannella and Rowe, 1995; Giambatista, 2004; Rowe et al., 2005). Most researchers have concentrated on searching for direct relationships between measures of leadership and various indicators of performance. This approach is oversimplified because in other parts of the literature the influence of certain variables is recognized as moderating the leadership-performance relationship. An insufficient focus on mediating variables may have led to a failure in previous studies to recognize indirect relationships or relationships mediated by intervening variables. Thus, it is important to identify and integrate potential mediating variables in future research into the leadership-performance relationship (Bass et al., 2003; Yukl, 1999).

In general, where mediating variables have been included in previous studies of the leadership-performance relationship they have focused on a restricted range of individual or dyadic variables such as LMX, personality measures and support of leadership. Most studies suggest these variables have important mediating roles in affecting the leadership-performance relationship. However, many other variables can potentially affect whether leadership 
influences organizational outcomes, including the degree of alignment between the prevailing leadership paradigm and follower behavior (Jing and Avery, 2008).

Three potentially important mediating variables arise from the literature, including variables that, although they can affect the organization more broadly, have been ignored in most studies of the leadership-performance relationship. These are vision, organizational climate, and trust between leader and followers. This represents a gap that is addressed in this paper by examining the influences of these three mediating variables on the proposed leadership-performance relationship. The literature regarding the anticipated roles of these three mediating variables in the leadership-performance relationship is reviewed and summarized next.

\section{MEDIATING ROLES OF VISION USE AND SHARING}

Many scholars suggest that vision-based leadership has positive effects on organizational performance (e.g. Bass, 1990; House and Aditya, 1997; Isenberg, 1987; Maccoby, 1981; Peters, 1987; Slater, 1993). Although there is lack of a clear definition of vision-based leadership (Kantabutra and Avery, 2002), two follower variables that affect organizational performance are commonly identified in the visionary leadership literature. These are followers' use of their leader's vision in guiding daily operations, and followers' emotional commitment to the vision (Kantabutra and Avery, 2004). These factors are important because a vision reflects the organization's central purpose and objectives, and can help followers determine which behavior is appropriate, important, or trivial. Thus, whether and how followers use a vision to guide their work could affect both individual and collective performance outcomes. In addition, vision inspires people by transcending a focus on the bottom line (Nanus, 1992). When followers are emotionally committed, they are willing, even eager, to commit voluntarily and completely to something that enables their organization to grow and progress. Thus, whether and how followers are emotionally committed to their leader's vision could affect both individual and organizational performance. Kantabutra and Avery (2004) propose that the stronger the commitment of followers, the better the organizational performance is likely to be.

Previous research suggests that how a vision is communicated will have direct effects on organizational performance (Baum, Locke and Kirkpatrick, 1998). According to the research findings of Kantabutra and Avery (2002), vision communication is one of the most essential factors in using visions within an organization. Vision communication can be measured via employees' responses to two items (Baum et al., 1998): (a) "Does your firm have a written vision?" and (b) "Has your manager talked about a vision ...?"

Furthermore, Kantabutra and Avery (2005) suggest that leader and follower sharing a vision has direct and positive effects on organizational performance as measured by staff and customer satisfaction. Therefore in future research, both vision communication and vision sharing should be employed as measures in researching the mediating role of vision in affecting the leadership-performance relationship.

Two non-financial measures that have often been adopted as performance indicators when measuring the effect of vision on organizational performance are customer satisfaction and employee satisfaction. According to Kantabutra and Avery (2004), there are three underlying justifications for using these measures: These indices are widely used in organizations; both customer satisfaction and employee satisfaction are more responsive to leaders' behavior within the short timeframe of most studies than financial measures; and employee satisfaction is closely correlated with customer satisfaction. Customer satisfaction can also be viewed as an indicator of other critical measures of business performance such as customer loyalty, profit, market share, and growth (Anderson, Fornell and Lehman, 1994; Bolton and Drew, 1991).

Moreover, staff emotional commitment to their store manager's vision has been found critical to enhanced organizational performance as measured by both customer and staff satisfaction (Kantabutra and Avery, 2004).

Overall, the findings of Kantabutra and Avery (2004) suggest that a positive relationship exists between a leader's vision use and customer and follower satisfaction in the retailing industry. However, their study did not 
associate the vision with particular leadership paradigms, nor did it focus on the meditating role of vision in the leadership-performance relationship. As vision is hypothesized to function as a mediating variable in researching the leadership-performance relationship, future studies can build on Kantabutra and Avery (2004) by focusing on vision as a key mediating variable.

Previous empirical findings lead to the prediction that when a vision is present and shared in an organization, organizational performance will be strengthened (Kantabutra and Avery, 2005). Jing and Avery (2008) suggest that the link between leadership and organizational performance is very important and leadership is also viewed by some researchers (e.g. Zhu, Chew and Spangler, 2005) as one of the key driving forces for improving a firm's performance. Under Avery's (2004) four leadership paradigms, it is obvious that under the visionary and organic leadership paradigms, visions will operate. However, it is also possible that transactional or classical leaders have a vision, even though their leadership style does not reflect other criteria of the visionary paradigm (e.g. collaborating with followers), and this vision may be sufficient to increase follower's and customer's satisfaction. Therefore, the role of vision should be examined under all paradigms.

In light of the above discussion, the following research propositions are suggested:

1a: Organizations in which leaders have a vision - irrespective of whether the prevailing leadership paradigm is classical, transactional, visionary or organic - display enhanced financial performance compared with organizations in which leaders have no vision.

1b: Organizations in which leaders have a vision - irrespective of whether the prevailing leadership paradigm is classical, transactional, visionary or organic - display enhanced customer satisfaction compared with organizations in which leaders have no vision.

1c: Organizations in which leaders have a vision - irrespective of whether the prevailing leadership paradigm is classical, transactional, visionary or organic - display enhanced staff satisfaction compared with organizations in which leaders have no vision.

In the literature, a vision shared between leader and follower has also been widely regarded as a key to high performance (e.g. Bass, 1985; House and Aditya, 1997; Howell and Shamir, 2005; Kantabutra and Avery, 2006a, 2006b; Reardon, 1991; Senge, 1990). Drath (2001) also suggested that effective leadership requires an alignment between leader and follower concepts of leadership, which further reinforces the importance of aligning and sharing visions held by organizational members operating under the visionary paradigm. Sashkin (1988) and Sims and Lorenzi (1992) have also argued that effective visions should be integrated into the visions of others in an organization.

Since the literature consistently points out the positive effects of vision sharing between leader and followers on organizational performance, vision sharing should be adopted as a mediator in future studies on leadership and performance.

Thus, the next set of research propositions is:

1d: Organizations in which the leader's vision is shared by their staff will display enhanced financial performance compared with organizations in which leaders have no shared vision with their staff, irrespective of leadership paradigm.

1e: Organizations in which the leader's vision is shared by their staff will display enhanced customer satisfaction compared with organizations in which leaders have no shared vision with their staff, irrespective of leadership paradigm.

1f: Organizations in which the leader's vision is shared by their staff will display enhanced staff satisfaction compared with organizations in which leaders have no shared vision with their staff, irrespective of leadership paradigm. 


\section{MEDIATING ROLE OF ORGANIZATIONAL CLIMATE}

Organizational climate originally referred to a range of environmental influences such as the psychological environment, social, organizational and situational influences on behavior (Argyris, 1958; Forehand and Gilmer, 1964; Guetzkow, Forehand and James, 1962). Many of the early studies tended to emphasize the importance of a particular kind of climate such as having the 'right type' of climate (Argyris, 1958) or the climate for participation and control created by managers (McGregor, 1960).

Climate has been described by Schneider, Gunnarson and Niles-Jolly (1994) as 'the feeling in the air' that one gets from walking around a company. According to Avery (2004), leaders can affect followers and organizational performance indirectly by actions such as creating an environment in which subordinates can work effectively, developing an appropriate culture that helps employees build commitment to the organizational goals, and formulating strategy. Consistent with this, Perryer and Jordan (2005) argue that leadership is usually regarded as the process of influencing people to achieve organizational objectives. Successful leaders tend to create a climate within the work environment where they are able to assist employees to set and achieve individual, team and, ultimately, organizational objectives (Perryer and Jordan, 2005).

Koene, Vogelaar and Soeters (2002) also indicated that organizational climate includes leader-member communication, that is the provision of information by the manager; organizational efficiency, clarity of tasks; and how much the readiness to innovate or find new approaches is encouraged in the unit. Koene et al. (2002) pointed out that a supportive organizational climate will positively affect both employee and organizational performance.

According to Clark (2002), organizational climate can be categorized and subdivided into five key themes: structure, rewards and recognition, cohesion, warmth and support, and customer care. Clark (2002) found a link between climate and performance in employees' perceptions of organizational climate relating to customer retention rates at a micro-organizational level in a UK bank.

Research suggests that climate perceptions are associated with a variety of important performance measures at the individual, group and organizational levels. These include leader behavior (Rentsch, 1990; Rousseau, 1988), turnover intentions (Rentsch, 1990; Rousseau, 1988), job satisfaction (James and Jones, 1980; James and Tetrick, 1986; Mathieu, Hoffman and Farr, 1993), individual job performance (Brown and Leigh, 1996; Pritchard and Karasick, 1973), and organizational performance (Lawler, Hall and Oldham, 1974; Patterson, 2005).

Therefore, future research should investigate the role of organizational climate as a key mediating variable in the leadership-performance relationship. Doing so involves a challenge due to the lack of a sound theoretical basis for many climate measuring instruments. This has resulted in considerable variation in measures of climate dimensions employed in different studies (Patterson, 2005). One of the best-known general measures of organizational climate is the Organizational Climate Questionnaire (OCQ) by Litwin and Stringer (1968). It comprises 50 items that assess nine dimensions of climate. However, Rogers, Miles and Biggs (1980) argued that the OCQ lacked validity and was not a consistent measurement device. This poses a measurement problem for organizational climate.

Some scholars (e.g. Koene et al., 2002) have suggested that organizational climate can be measured with three scales namely: organizational efficiency, general communication, and readiness to innovate as used elsewhere (De Cock et al., 1984; Koene et al., 2002; Payne and Mansfield, 1978). Organizational efficiency can indicate clarity of tasks, general communication measures the provision of information by the manager, and readiness to innovate indicates the degree to which finding new approaches is encouraged. Two other essential scales to measure organizational climate recommended by Clark (2002) are cohesion and warmth. Thus, future studies of the leadership-performance relationship could employ the above-mentioned scales for measuring organizational climate. 
The literature leads to the prediction that organizations with warm and supportive climates will be associated with enhanced organizational performance. Linking this to the characteristics of Avery's (2004) leadership paradigms suggests that warm and supportive leadership climates would be associated with visionary and organic leadership paradigms. Although classical and transactional leadership could also harbor a warm and supportive climate, it is generally expected that the organizational climate under transactional leadership would be lower or less frequently warm and supportive than found under visionary and organic leadership environments. In particular, the climate is least likely to be warm and supportive for classical leadership (especially where fear operates rather than respect for the leader).

Thus, another set of research propositions emerging from this discussion includes:

2a: Organizations in which leaders use visionary and organic leadership styles exhibit more warm and supportive organizational climates than organizations in which leaders use classical and transactional leadership styles.

2b: Organizations with warm and supportive organizational climates exhibit enhanced organizational financial performance compared with organizations with less warm and supportive organizational climates.

2c: Organizations with warm and supportive organizational climates exhibit enhanced customer satisfaction compared with organizations with less warm and supportive organizational climates.

2d: Organizations with warm and supportive organizational climates exhibit enhanced staff satisfaction compared with organizations with less warm and supportive organizational climates.

\section{MEDIATING ROLE OF TRUST BETWEEN LEADER AND FOLLOWERS}

The significance of trust in leadership has been recognized by researchers for at least four decades, in both books (e.g. Argyris, 1962; Likert, 1967; McGregor, 1967) and empirical articles (e.g. Mellinger, 1959; Read, 1962). Trust can be defined in terms of the extent to which one believes in and is willing to depend on another party. Some people include the idea of making oneself vulnerable to the other (Mayer, Davis and Schoorman, 1995; McKnight, Cummings and Cheryany, 1998).

The evidence for the effect of trust on performance is widespread. Management and employees can more effectively achieve organizational goals and improve organizational performance if they trust and cooperate with each other (Dirks and Ferrin, 2002). Thus, theoretically, from a managerial perspective, showing respect and trust towards employees can be positive to the extent that it generates reciprocal trust. It also generates greater power by facilitating less friction in organizational relations (Clegg, 1997).

Dirks and Ferrin's (2002) theoretical analysis revealed two different mechanisms by which trust might affect behavior and performance. The first, a character-based perspective, focuses on how perceptions of the leader's character affect a follower's vulnerability in a hierarchical relationship. Mayer et al. (1995) provided a model proposing that when followers believe their leaders have integrity, capability or benevolence, they will be more comfortable engaging in behaviors that put them at risk (e.g. sharing sensitive information). Mayer and Gavin (1999) suggested that when employees believe their leader cannot be trusted (e.g. because the leader is perceived not to have integrity), they will divert energy toward 'covering their backs', which detracts from their work performance.

A second approach, the relationship-based perspective, is based on principles of social exchange (Dirks and Ferrin, 2002). It deals with employees' willingness to reciprocate care and consideration that a leader may express in a relationship. That is, individuals who feel that their leader has, or will, demonstrate care and consideration will reciprocate this sentiment in the form of desired behaviors. Konovsky and Pugh (1994) drew on this logic to suggest that a social exchange relationship encourages individuals to spend more time on required tasks and be willing to go above and beyond their job role. Both theoretical perspectives suggest that trust may result in higher organizational performance (Dirks and Ferrin, 2002), but they raise performance by distinct, and potentially complementary, routes. 
Given the volume of literature on the nature of trust, there is surprisingly little agreement on the operationalization of the concepts. According to Sako (1992, p.37), trust is one's confidence in another that 'the other behaves or responds in a predictable and mutually acceptable manner'. Sako, drawing on findings from her cross-country case research on manufacturer-supplier relationships in the electronics industries in Britain and Japan, identified three components of inter-organizational trust essential to improve organizational performance. Each of these three concepts is captured in only a single item. They are contractual trust (i.e. one's expectations that an exchange partner keeps its promises), competence trust (i.e. one's confidence in the exchange partner's competence, or professional standard, in carrying out specific tasks), and goodwill trust (i.e. one's confidence in its exchange partner's open commitment to supporting and continuing a focal exchange relationship).

Many scholars have suggested that trust between management and followers is linked to a number of attitudinal outcomes, particularly job satisfaction (Bass, 1990; Dirks and Ferrin, 2002; Hogan, Curphy and Hogan, 1994; Wang and Clegg, 2002). A high level of trust between management and followers may result in higher organizational financial performance and job satisfaction (Casimir, et al., 2006; Clegg, 1989, 1997; Dirks and Ferrin, 2002; Mayer et al., 1995). Employees' participation in decision making is a dynamic process, which is affected by the level of trust between management and employees. In other words, true employee involvement, which enhances management effectiveness and organizational financial performance, is a result of an interaction of mutual trust between management and employees (Wang and Clegg, 2002). Purely power-based leadership based on ownership, control or trusteeship of material or intellectual assets may keep employees working but is not a sustainable basis for motivating others or for generating emotional, spiritual commitment.

Among theories of leadership, trust has perhaps been most frequently cited in the literature on visionary leadership (Dirks and Ferrin, 2002). According to various scholars (e.g. Podsakoff et al., 1990), visionary leaders engage in actions that gain the trust of their followers, and this in turn results in desirable outcomes. Pillai, Schriesheim and Williams (1999) suggested that visionary leaders may operate by establishing a social exchange relationship with followers. For instance, visionary leaders may build trust by demonstrating individualized concern and respect for followers (Jung and Avolio, 2000). Thus, organizations operating under visionary leadership will show a moderate degree of trust. In contrast, transactional leaders are said to focus more effort on ensuring that employees are rewarded fairly (contingent reward) and that followers recognize that they will benefit by fulfilling the work contract. Compared with visionary leadership behavior, transactional leaders seem to put less emphasis on the relationship and more emphasis on ensuring that they are seen as fair, dependable, and having integrity (character-based issues). Organic organizations are predicted to enjoy the highest degree of trust because their members are expected to be self-managing and self-leading, and they need to show the highest character or relationship-based trust between each other when working together.

The literature suggests that both transactional and visionary leadership should engender trust, which in turn may be necessary if follower performance is to be maximized. Transactional leaders who tie staff up with detailed legal contracts, generally base trust on employees fulfilling the agreements, as well as on the leader's reward and coercion power. Followers trust transactional leaders, partly because they believe leaders are concerned about their welfare and needs, such as job security and working conditions (Casimir, et al., 2006).

In contrast, visionary leaders do not supervise or control staff nearly as closely, especially in dynamic environments, and they may have to rely more on trust that employees are heading in the direction of the vision. Visionary leaders build trust by frequently empowering and encouraging followers to make their own decisions (Avolio and Bass, 1995). This trust then builds confidence and encourages or inspires followers to exert extra effort for the leader and the organization, thus resulting in enhanced performance (Casimir, et al., 2006).

The literature also suggests that strong trust in the leader is likely to be an outcome of visionary leadership behavior (Podsakoff et al., 1990), and that it may be a key mediating mechanism in understanding the performance-enhancing effect of such leadership (Casimir et al., 2006). According to Podsakoff et al. (1990), followers who trust their leaders are likely to both exert extra effort and obtain increased levels of intrinsically-based 
satisfaction because of the positive emotions associated with trust. In this way, trust can operate as a mediator in the leadership-performance relationship.

An examination of the literature reveals support (e.g. Ba and Pavlou, 2002; Miyamoto and Rexha, 2004) for several efficient indicators to measure the level of trust as suggested by Sako (1992). Trust between the leader and his or her followers is measured by contractual trust, competence trust, and goodwill trust, respectively (Sako, 1992). Thus, these measurements could be employed in future studies of the mediating role of trust in affecting the leadership-performance relationship.

Some researchers (e.g. Bass et al., 2003; Shamir and Howell, 1999; Yukl, 1999) have argued that existing research into the leadership-performance relationship is inadequate because it ignores important mediating variables that could link leadership style to performance (Bass et al., 2003; Yukl, 1999). For instance, some researchers (e.g. Boies and Howell, 2006; Dirks and Ferrin, 2002) demonstrated the importance of trust as mediator in their leadership-performance studies. However, they failed to consider and employ other mediating variables when researching the leadership-performance relationship, such as organizational climate. House and Aditya (1997) also complained that the leadership research that they reviewed excluded several functions that leaders perform, as well as organizational and environmental variables crucial to effective leadership.

Under Avery's (2004) leadership paradigms, different kinds and degrees of trust are likely to be associated with different leadership paradigms. For example, low trust can be used for classical and transactional leadership, moderate for visionary leadership, and high for organic leadership because of the interdependency of the members.

The research propositions emerging from this section are:

3a: Organizations in which leaders use visionary and organic leadership styles exhibit higher levels of trust between leaders and staff compared with organizations in which leaders use classical and transactional leadership styles.

3b: Organizations with high levels of trust between leaders and staff exhibit enhanced organizational financial performance compared with organizations with lower levels of trust between leaders and staff.

3c: Organizations with high levels of trust between leader and staff exhibit enhanced customer satisfaction compared with organizations with low levels of trust between leader and staff.

3d: Organizations with high levels of trust between leaders and staff exhibit enhanced staff satisfaction compared with organizations with low levels of trust between leaders and staff.

In sum, relatively few studies of the link between leadership and performance investigate the role of different mediating variables, let alone the effects of multiple variables taken together. The literature suggests that some variables may be crucial to mediating the leadership-performance relationship that are normally ignored by researchers (Boies and Howell, 2006; Judge et al., 2002; Judge, Heller and Mount, 2002; Judge and Ilies, 2002; Judge and Piccolo, 2004; Keller, 2006; Lim and Ployhart, 2004). The above sections attempt to rectify shortcomings in existing research by recognizing the intervening effects of three mediating variables (i.e. vision, organizational climate, and trust between leader and followers) and the need to include multiple variables when researching the leadership-performance relationship. Fourteen research propositions for future research have emerged.

\section{CONCLUSION AND GAPS IN THE LITERATURE}

Despite the leadership efficacy claimed in the literature, the overall status of research into the leadership-performance relationship is inconclusive. Many scholars have critically examined the effectiveness of leadership paradigms and behaviors (Analoui, 1999; Avery, 2004; Drath, 2001; House and Aditya, 1997; Kakabadse and Kakabadse, 1999; Shamir et al. 1993; Shamir and Howell, 1999; Yukl, 1999). They conclude that existing research on the leadership-performance relationship is full of difficulties and has many unsolved problems. This paper highlights problems and gaps regarding three mediating variables likely to affect the leadership-performance 
relationship.

One problem is that despite suggestions in the literature that several key mediating variables intervene in the leadership-performance relationship, no previous study has fully considered and integrated these variables. Some of the neglected mediating variables include vision, organizational climate, and trust between leader and followers. Most prior studies have been concerned with at best only one of these variables, ignoring the others and their potential interactions in exploring the leadership-performance relationship. Because these variables can be regarded as key mediators of leadership in affecting organizational performance, previous studies do not fully reveal the comprehensive influence of mediating variables when researching the relationship between leadership paradigms and performance. This paper addresses this gap.

Additionally, previous studies have clearly demonstrated a relationship between individual key mediating variables and organizational performance. For example, Kantabutra and Avery (2004) described the relationship between vision and organizational performance, but did not associate the mediating variables with different leadership paradigms. Thus, there is a lack of research into the relationship between identified mediating variables linking leadership paradigms and organizational performance.

In sum, despite increased research into the leadership-performance relationship, there are many problems and gaps in existing studies. No clear picture has emerged. There is a lack of integration concerning the relationship between leadership and performance, a narrow set of variables has been used in previous studies, and some important mediating variables affecting the leadership-performance relationship have been ignored. Therefore, 14 research propositions have been developed throughout this paper to guide further research into addressing these problems.

\section{AUTHOR INFORMATION}

Fenwick Feng Jing is a Doctor of Business Administration student within the Institute for Sustainable Leadership at Macquarie Graduate School of Management. He holds a BA from Shandong Normal University, China and an MSc from Lancaster University, UK. He currently researches leadership and organizational performance. Previously, he served as a government official in China and management consultant in Shanghai, specializing in human resource services and management development.

Gayle C. Avery, Professor of Management, heads the Institute for Sustainable Leadership at Macquarie Graduate School of Management. She holds a PhD in psychology from Monash University. Her area of specialization is leadership, particularly leadership required for creating sustainable organizations. Author of Understanding Leadership and Leadership for Sustainable Futures, her research has appeared in many journals. She advises senior executives in a wide range of organizations on leadership.

\section{REFERENCES}

1. Analoui, F. (1999) Eight parameters of managerial effectiveness. Journal of Management Development, 18(4):362-389.

2. Anderson, E.W., Fornell, C. and Lehman, D.R. (1994) Customer satisfaction, market share, and profitability: Findings from Sweden. Journal of Marketing, 58:53-66.

3. Argyris, C. (1958) Some problems in conceptualizing organizational climate: A case study of a bank. Administrative Science Quarterly, 2:501-520.

4. Argyris, C. (1962) Interpersonal Competence and Organizational Effectiveness. Homewood, IL: Dorsey Press.

5. $\quad$ Avery, G.C. (2004) Understanding Leadership: Paradigms and Cases. London: Sage. 
6. Avolio, B.J. and Bass, B.M. (1995) Individual consideration viewed at multiple levels of analysis: A multi-level framework for examining the diffusion of transformational leadership. The Leadership Quarterly, 6(2):199-218.

7. Ba, S. and Pavlou, P. A. (2002) Evidence of the effect of trust building technology in electronic markets: Price premiums and buyer behavior. MIS Quarterly, 26(3):243-268.

8. $\quad$ Bass, B.M. (1985) Leadership and Performance Beyond Expectations. New York, NY: Free Press.

9. Bass, B.M. (1990) From transactional to transformational leadership: Learning to share the vision. Organizational Dynamics, 18(3):19-31.

10. Bass, B.M., Avolio, B.J., Jung, D.I. and Berson, Y. (2003) Predicting unit performance by assessing transformational and transactional leadership. Journal of Applied Psychology, 88(2):207-218.

11. Baum. J.R., Locke, E.A. and Kirkpatrick, S.A. (1998) A longitudinal study of the relation of vision and vision communication to venture growth in entrepreneurial firms. Journal of Applied Psychology, 83(1):43-54.

12. Boies, K. and Howell, J.M. (2006) Leader-member exchange in teams: An examination of the interaction between relationship differentiation and mean LMX in explaining team-level outcomes. The Leadership Quarterly, 17(3):246-257.

13. Bolton, R.N. and Drew, J.H. (1991) A multistage model of customers' assessment of service quality and value. Journal of Consumer Research, 54(4):69-82.

14. Brown, S.P. and Leigh, T.W. (1996) A new look at psychological climate and its relationship to job involvement, effort, and performance. Journal of Applied Psychology, 81:358-368.

15. Cannella Jr., A.A. and Rowe, W.G.. (1995) Leader capabilities, succession and competitive context: A baseball study. The Leadership Quarterly, 1:69-88.

16. Casimir, G., Waldman, D.A., Bartram, T. and Yang, S. (2006) Trust and the relationship between leadership and follower performance. Journal of Leadership \& Organizational Studies, 12(3):68-84.

17. Clark, M. (2002) The relationship between employees' perceptions of organizational climate and customer retention rates in a major UK retail bank. Journal of Strategic Marketing, 10(2):93-113.

18. Clegg, S.R. (1989) Framework of Power. London: Sage.

19. Clegg, S.R. (1997) Power. In the Concise International Encyclopaedia of Business and Management, edited by Warner, M. London: Thomson, 567-577.

20. De Cock, G., Bouwen, R., De Witte, K. and De Visch, J. (1984) Organisatieklimaat en-cultuur: Theorie en Praktische Toepassing van de Organisatieklimaat-index voorr Profit-Organisaties (OKIPO) en de Verkorte Vorm (VOKIPO). Leuven: ACCO.

21. Dirks, K.T. and Ferrin, D.L. (2002) Trust in leadership: Meta-analytic findings and implications for research and practice. Journal of Applied Psychology, 87(4):611-628.

22. Drath, W.H. (2001) The Deep Blue Sea: Rethinking the Source of Leadership. San Francisco. CA: Jossey-Bass.

23. Forehand, G.A. and Gilmer, B.V.H. (1964) Environmental variation in studies of organizational behavior. Psychological Bulletin, 62:228-240.

24. Giambatista, R.C. (2004) Jumping through hoops: A longitudinal study of leader life cycle in the NBA. The Leadership Quarterly, 15:607-624.

25. Guetzkow, H., Forehand, G.A. and James, B.J. (1962) An evaluation of educational influence on executive judgment. Administrative Science Quarterly, 6:483-500.

26. Hogan, R., Curphy, G.. and Hogan, J. (1994) What we know about leadership: Effectiveness and personality. American Psychologist, 49:493-504.

27. House, R.J. and Aditya, R.N. (1997) The social scientific study of leadership: Quo Vadis? Journal of Management, (23)3:409-473.

28. Howell, J.M. and Shamir B. (2005) The role of followers in the charismatic leadership process: Relationships and their consequences. Academy of Management Review, 30(1):96-112.

29. Isenberg, D.J. (1987) The tactics of strategic opportunism. Harvard Business Review, 92-97.

30. James, L.R. and Jones, A.P. (1980) Perceived job characteristics and job satisfaction: An examination of reciprocal causation. Personnel Psychology, 33:97-135. 
31. James, L.R. and Tetrick, L.E. (1986) Confirmatory analytic tests of three causal models relating job perceptions to job satisfaction. Journal of Applied Psychology, 71:77-82.

32. Jing, F.F. and Avery, G.C. (2008) Missing links in understanding the relationship between leadership and organizational performance. International Business \& Economics Research Journal, 7(5):67-78.

33. Judge, T.A., Bono, J.E., Ilies, R. and Gerhardt, M.W. (2002) Personality and leadership: A qualitative and quantitative review. Journal of Applied Psychology, 87(4):765-780.

34. Judge, T.A., Heller, D. and Mount, M.K. (2002) Five-factor model of personality and job satisfaction: A meta-analysis. Journal of Applied Psychology, 87(3):530-541.

35. Judge, T.A. and Ilies, R. (2002) Relationship of personality to performance motivation: A meta-analytic review. Journal of Applied Psychology, 87(4):797-807.

36. Judge, T.A. and Piccolo, R.F. (2004) Transformational and transactional leadership: A meta-analytic test of their relative validity. Journal of Applied Psychology, 89(5):755-768.

37. Jung, D. and Avolio, B. (2000) Opening the black box: An experimental investigation of the mediating effects of trust and value congruence on transformational and transactional leadership. Journal of Organizational Behavior, 21:949-964.

38. Kakabadse, A. and Kakabadse, N. (1999) Essence of Leadership (Global Manager). London: Thomson Learning.

39. Kantabutra, S. and Avery, G.C. (2002) Proposed model for investigating relationships between vision components and business unit performance. Journal of the Australian \& New Zealand Academy of Management, 8(2):22-39.

40. Kantabutra, S. and Avery, G.C. (2004) Filling in the gap: An inclusive model relating vision-based leadership and organizational performance. European Applied Business Research Conference. 14-18 June, Edinburgh.

41. Kantabutra, S. and Avery, G.C. (2005) Essence of shared vision: Empirical investigation. New Zealand Journal of Human Resources Management, 5:1-28.

42. Kantabutra, S. and Avery, G.C. (2006a) Follower effects in the visionary leadership process. Journal of International Business \& Economics Research, 4(5):57-66.

43. Kantabutra, S. and Avery, G.C. (2006b) Shared vision in customer and staff satisfaction: Relationship and their consequences. Asia Pacific Journal of Economics \& Business, 4(5):57-66.

44. Keller, R.T. (2006) Transformational leadership, initiating structure and substitutes for leadership: A longitudinal study of research and development project team performance. Journal of Applied Psychology, 91(1):202-210.

45. Koene, B.A.S., Vogelaar, A.L.W. and Soeters, J.L. (2002) Leadership effects on organizational climate and financial performance: Local leadership effect in chain organizations. The leadership Quarterly, 13:193-215.

46. Konovsky, M. and Pugh, D. (1994) Citizenship behavior and social exchange. Academy of Management Journal, 37:656-669.

47. Lawler, E.E., Hall, D.T. and Oldham, G.R. (1974) Organizational climate: relationship to organizational

48. $\quad$ structure, process and performance. Organizational Behavior \& Performance, 11: 139-155.

49. Likert, R. (1967) The Human Organization: Its Management and Value. New York: McGraw-Hill.

50. Lim, B. and Ployhart, R.E. (2004) Transformational leadership: Relations to the five-factor model and team performance in typical and maximum contexts. Journal of Applied Psychology, 89(4):610-621.

51. Litwin, G.H. and Stringer, R.A. (1968) Motivation and Organizational Climate. Boston, MA: Harvard University Press.

52. Maccoby, M. (1981) The Leader. New York: Simon and Schuster.

53. Mathieu, J.E., Hoffman, D.A. and Farr, J.L. (1993) Job perceptions-job satisfaction relations: An empirical comparison of three competing theories. Organizational Behavior \& Human Decision Processes, 56:370-387.

54. Mayer, R.C., Davis, J.H. and Schoorman, F.D. (1995) An integrative model of organizational trust. Academy of Management Review, 20:709-734. 
55. Mayer, R.C. and Gavin, M.B. (1999) Trust for management and performance: Who minds the shop while the employees watch the boss? Annual Meeting of the Academy of Management, Chicago.

56. McGregor, D. (1960) The Human Side of Enterprise. New York: McGraw-Hill.

57. McGregor, D. (1967) The Professional Manager. New York: McGraw-Hill.

McKnight, H., Cummings, L.L. and Cheryany, N. (1998) Initial trust formation in new organizational

58. relationship. Academy of Management Review, 23:473-490.

59. Mellinger, G. (1959) Interpersonal trust and communication. Journal of Abnormal \& Social Psychology, 52:304-309.

60. Miyamoto, T. and Rexha, N. (2004) Determinants of three facets of customer trust: A marketing model of Japanese buyer-supplier relationship. Journal of Business Research, 57(3):312-319.

61. Nanus, B. (1992) Visionary Leadership: Creating a Compelling Sense of Direction for Your Organization. San Francisco: Jossey-Bass.

62. Patterson, K. A. (2005) Leadership practices. Regent University Law School Admissions, Virginia Beach, Virginia.

63. Payne, R. and Mansfield, R. (1978) Correlates of individuals' perceptions of organization climates. Journal of Occupational Psychology, 51:209-218.

64. Perryer, C. and Jordan, C. (2005) The influence of leader behaviors on organizational commitment: A study in the Australian public sector. International Journal of Public Administration, 28:379-396.

65. Peters, T.J. (1987) Thriving on Chaos: Handbook for a Management Revolution. New York: Harper and Row.

66. Pillai, R., Schriesheim, C. and Williams, E. (1999) Fairness perceptions and trust as mediators for transformational and transactional leadership: A two-sample study. Journal of Management, 6:897-933.

67. Podsakoff, P., MacKenzie, S., Moorman, R. and Fetter, R. (1990) Transformational leader behaviors and their effects on followers' trust in leader, satisfaction and organizational citizenship behaviors. The Leadership Quarterly, 1:107-142.

68. Pritchard, R.D. and Karasick, B.W. (1973) The effect of organizational climate on managerial job performance and job satisfaction. Organizational Behavior \& Human Performance, 9:126-146.

69. Read, W.H. (1962) Upward communication in industrial hierarchies. Human Relations, 15:3-15.

70. Reardon, K. (1991) Persuasion in Practice. Newbury Park, CA: Sage.

71. Rentsch, J. (1990) Climate and culture: Interaction and qualitative differences in organizational meanings. Journal of Applied Psychology, 75:668-681.

72. Rogers, E.D., Miles, W.G. and Biggs, W.D. (1980) The factor replicability of the Litwin and Stringer Organizational Climate Questionnaire: An inter- and intra-organizational assessment. Journal of Management, 6:65-78.

73. Rousseau, D.M. (1988) The construction of climate in organization research. In C.L. Cooper and I.T. Robertson (eds), International Review of Industrial and Organizational Psychology, Chichester: Wiley, 3:139-59.

74. Rowe, W.G., Cannella Jr., A.A., Rankin, D. and Gorman, D. (2005) Leader succession and organizational performance: Integrating the common-sense, ritual scapegoating and vicious-circle succession theories. The leadership Quarterly, 16(2):197-219.

75. Sako, M. (1992) Prices, Quality and Trust: Inter-Firm Relations in Britain and Japan. Cambridge, UK: Cambridge University Press.

76. Sashkin, M. (1988) Visionary leadership. In J. Conger, R. Kanungo and Associates Charismatic Leadership: The Elusive Factor in Organizational Effectiveness. San Francisco, CA: Jossey-Bass.

77. Schneider, B., Gunnarson, S. and Niles-Jolly, K. (1994) Creating the climate and culture of success. Organizational Dynamics, 23:17-29.

78. Senge, P.M. (1990) The Fifth Discipline: The Art and Practice of the Learning Organization. Broadway, NY: Publishing Group, Inc.

79. Shamir, B., House, R.J. and Arthur, M.B. (1993) The motivational effects of charismatic leadership: A self-concept based theory. Organization Science, 4(4):577-594. 
80. Shamir, B. and Howell, J.M. (1999) Organizational and contextual influences on the emergence and effectiveness of charismatic leadership. The Leadership Quarterly, 10(2):257-283.

81. Sims, H.P. and Lorenzi, P. (1992) The New Leadership Paradigm: Social Learning and Cognitions in Organizations. Newbury Park, CA: Sage.

82. Slater, R. (1993) The New GE: How Jack Welch Revived an American Institution. Homewood, IL: Business One Irwin.

83. Wang, K.Y. and Clegg, S. (2002) Trust and decision making: Are managers different in the People's Republic of China and in Australia. Cross Cultural Management, 9(1):30-45.

84. Yukl, G. (1999) An evaluative essay on current conceptions of effective leadership. European Journal of Work \& Organizational Psychology, 8(1):33-48.

85. Zhu, W., Chew, I.K.H. and Spangler, W.D. (2005) CEO transformational leadership and organizational outcomes: The mediating role of human-capital-enhancing human resource management. The Leadership Quarterly, 16(1): 39-52. 